\title{
Performance evaluation of roof top solar photovoltaic systems in Tamilnadu
}

\author{
M. Aravindan', V. Balaji ${ }^{2}$, V. Saravanan ${ }^{3}$, M. Arumugam ${ }^{4}$ \\ ${ }^{1}$ Department of Electrical and Electronics Engineering, Sri Chandrasekarendra Saraswathi Viswa Maha Vidyalaya \\ (SCSVMV) University, India \\ ${ }^{2}$ School of Electrical Engineering, Bahir Dar University, Ethiopia \\ ${ }^{3,4}$ Department of Electrical and Electronics Engineering, Arunai Engineering College, India
}

\begin{tabular}{l}
\hline \hline Article Info \\
\hline Article history: \\
Received Jan 17, 2019 \\
Revised Apr 9, 2019 \\
Accepted Apr 20, 2019
\end{tabular}

Keywords:

Energy yield

Modelling

Online monitoring

Performance evaluation

Rooftop solar photovoltaic

system

\begin{abstract}
This manuscript reports the monitored performance results of roof top solar photovoltaic (PV) power plants in different parts of Tamilnadu, India. In this work, PV plants of capacities $84 \mathrm{kWp}$ and $18 \mathrm{kWp}$ located at Tirunelveli and Ranipet respectively in Tamilnadu are considered. During an eight month period, of September 2014 to April 2015, these plants had generated 43.99 MWh and 15.55 MWh units of electricity respectively. The average electricity production per day for the considered period of these plants is $181.74 \mathrm{kWh}$ and $62.81 \mathrm{kWh}$ respectively. The performance ratio (PR) of these plants PV1 and PV2 is found to be 0.52 and 0.86 respectively. The characteristics of poly crystalline PV modules and the performance of employed photovoltaic inverters are also analyzed.It is observed that external conditions like climate and bad weather significantly reduces the PV system output, whereas it reduces marginally due to inverter failure as observed from the values of energy yield and performance ratio of these plants. Online monitoring of PV plant with DC/AC line and phase voltages and current waveforms observed for the given day are also presented.
\end{abstract}

Copyright $\odot 2019$ Institute of Advanced Engineering and Science. All rights reserved.

\section{Corresponding Author:}

V. Saravanan,

Departement of Electrical and Electronics Engineering,

Arunai Engineering College,

Tiruvannamalai 606 603, Tamilnadu, India.

Email: vsaranaec@yahoo.co.in

\section{INTRODUCTION}

Progress and development are happening in the field of solar photovoltaic systems in India by means of central and state government policies through financial schemes and subsidies such as capital subsidy, production subsidy (feed in tariffs), net metering, and initiatives from project developers, declining PV system costs and increase in operational efficiency by module/inverter manufacturers etc. India's commitment towards increased renewable power addition, carbon emission reduction and meeting energy requirement for its needs from solar is studied through modeled growth trajectory having total installed PV capacity of $2600 \mathrm{GW}$ by the year 2050 is discussed [1-3]. Government of India had revised the target of grid connected solar power projects to $100 \mathrm{GW}$ by the year 2022. Of which grid connected rooftop solar PV systems should have capacity addition of about $40 \mathrm{GW}$ through spare roof space available in the institutional, industrial, commercial and housing sectors. The remaining $60 \mathrm{GW}$ should be realized through medium and large scale grid connected solar power parks. However, the estimated solar power potential in India is about 748.98 GWp and in Tamilnadu is about 17.67 GWp. As on July 2018, 21892.42 MW of grid interactive (ground mounted) and $1222.65 \mathrm{MW}$ (roof top) solar photovoltaic (SPV) power was generated and $761.55 \mathrm{MW}_{\mathrm{EQ}}$ off grid SPV system was put in service throughout India [4-5]. 
Solar energy is a mainstream energy source and it contributes for sustainable energy, expected to provide more green jobs, reduce $\mathrm{CO}_{2}$ and water footprint of Tamil Nadu. Tamilnadu has reasonably high solar insolation $\left(5.6-6.0 \mathrm{kWh} / \mathrm{m}^{2}\right)$ with around 300 clear sunny days in a year with average solar irradiation is about $1266.52 \mathrm{~W} / \mathrm{m}^{2}$. The indicative power evacuation capacity available in various districts of Tamilnadu for connecting solar power plants is estimated as $11.10 \mathrm{GW}$ [6]. Tamilnadu Energy Development Agency (TEDA), an enterprise of Government of Tamilnadu plays a vital role in the growth of renewable energy especially solar power in the state. It had released the empanelled installers details of roof top solar photovoltaic system in various districts of Tamilnadu, with a bench mark cost of around INR 5,90,000 with 5 years comprehensive maintenance contract for $7 \mathrm{~kW}$ system and INR 7,83,000 with 5 years comprehensive maintenance contract for $10 \mathrm{~kW}$ system. The cost details/kWp (minimum-maximum value) of various empanelled vendors classified under capital expenditure categories are mentioned: i) 1-10kWp category ( INR 60,000-INR 69, 877), ii)11-100 kWp category (INR 57, 100-INR 64, 500), iii)101-500 kWp category (INR 56, 482-INR 59, 300). It also invited tenders and expression of interest from solar park developers for the establishment of solar parks in Tamil Nadu and the details are: i) Tender for design, supply, installation, commissioning \& 15 year operation and maintenance of grid tied solar power plants of $170 \mathrm{kWp}$ $(150 \mathrm{kWp}+20 \mathrm{kWp})$ at Irumbai Village in Tamil Nadu. (Tender reference: TEDA/3813/Irumbai VillageSPV/2018-19, Advertised on 08.05.2018), ii) Tender for supply, installation, commissioning and 15 years comprehensive maintenance of grid tied ground mounted solar power plant of cumulative capacity of $95 \mathrm{kWp}$ in the premises of SIDCO Industrial Estate Kakalur, Thiruvallur Tamil Nadu (Tender reference: TEDA/3810/SIDCO/Tender/TEDA/2018-19, Advertised on 08.05.2018), iii) Tender for development of solar park and establishment of $50 \mathrm{MW}$ (AC) grid connected solar power plant on "Build, Own, Operate, Transfer" model in Kayathar, Thoothukudi district through reverse bidding process. (Ref: TEDA/4566/50MW(AC)-Kayathar/2017-18). Tamil Nadu Solar Energy Policy 2018 is drafted by TEDA, which intends to create a framework that enables an accelerated development of solar energy in the state in support with Government of India. It aims to create a total installed capacity of 8,884 MW of solar energy by the year 2022 in Tamilnadu of which $40 \%$ (3,553MW) is expected to come from consumer scale (rooftop) solar systems. It has wide variety of operating mechanisms such as solar energy gross feed-in, solar energy wheeling (both utility scale), solar energy gross feed-in (consumer scale), solar energy net feed-in, solar energy group net-metering and solar energy virtual net feed-in. Solar energy gross and net feed-in tariffs will be determined by Tamil Nadu Electricity Regulatory Commission taking into consideration different capital costs based on the solar system capacity. It has various mandates such as i) any building type that requires being energy conservation building code (ECBC)-compliant will follow ECBC compliance guidelines for the installation of solar PV and solar thermal energy systems, ii) all public buildings in the state will be mandated to meet $30 \%$ of their energy requirements from solar energy by 2022 , iii) Streetlights and water supply installation of corporations, municipalities and local urban bodies are mandated to meet $30 \%$ of their energy requirements from solar energy by 2022 and iv) All state government departments of Tamilnadu should replace $10 \%$ of their existing vehicle fleet with solar powered, electric vehicles by 2022 [7, 8].

The performance of solar photovoltaic systems should be assessed under varying climatic, geographic and environmental conditions to know its operation and maintenance. The performance of the PV system is influenced by environmental factors such as solar irradiance, module temperature, dust accumulation and soiling/shading (external), PV system factors such as I-V characteristics, PV panel/ inverter efficiency (internal), PV system installation factors such as cable characteristics, orientation of PV panels, Mismatch effects, tracking mechanism, glass breakage, hotspots, series/shunt resistances of PV panels (operational) [9-11]. Earlier related literatures deals with performance evaluation of large and small scale grid connected solar photovoltaic systems in Tamilnadu, India and other parts of the world are discussed here. Few of the works are: Performance study of grid connected $20 \mathrm{kWp}$ solar photovoltaic installations in an industry in Tiruchirappalli, Tamilnadu is dealt in [12]. Experimental evaluation and validation of solar photovoltaic power systems at other different locations in India are recorded in [13-19]. Performance analysis of roof mounted and building integrated grid connected photovoltaic systems of various capacities throughout different parts of the world during past six years analyzing its energy yield, performance ratio for a certain period are discussed [20-28].

The objective of this paper is to provide details about performance of solar rooftop photovoltaic power plants in Tamilnadu which will be helpful for encouraging the solar power developers to have new solar photovoltaic power generation systems, inorder to realize the state and national targets in 2022.

\section{PV POWER PLANT LOCATION INFORMATION}

In this work, performance of roof top solar photovoltaic systems at different locations in Tamilnadu is calculated for eight month period, of September 2014 to April 2015. These systems consists of 
polycrystalline silicon PV modules connected to Fronius IG Plus (150 V-3), Symo 17.5-3-M/FRONIUS DC/AC inverter installed on the supporting structure, plus array junction boxes and data logging system. Typically, these PV systems are mounted on a stainless steel support structure facing south and tilted at angle of $15^{\circ}$. This paper validates the performance of these European inverters which are well suited for Indian climate conditions. The geographical locations of grid tied roof top solar power plants divided into:

- PV Plant 1: Hotel AAR Royal Residency, Tirunelveli: The plant is located at the geographical location of $8^{\circ} 43^{\prime} 48^{\prime \prime} \mathrm{N}, 77^{\circ} 42^{\prime} \mathrm{E}$ GPS co ordinates and altitude $60 \mathrm{~m}$.

- PV Plant 2: Snap Alginate and Natural Products, Ranipet: The plant is located at the geographical location of $12^{\circ} 57^{\prime} 35.1360^{\prime \prime} \mathrm{N} 79^{\circ} 18^{\prime} 11.1060^{\prime \prime}$ E GPS co ordinates and altitude $10 \mathrm{~m}$.

These PV plants are exposed to solar insolation of value ranging from 5.4 to $5.8 \mathrm{~kW} / \mathrm{m} 2$ throughout the year. The performance of PV systems depends on meteorological factors (solar irradiance characteristics, wind speed and ambient temperature) and installation site factors (latitude, orientation, dust, pollution level and tree cover). The details of energy yield of PV system in a given location are important, while designing for a particular application.

\section{DESCRIPTION OF PV POWER PLANT}

This section explains the PV power plant details. Table 1 gives specification of the PV power plant, all commissioned in the year 2014. PV power plant installations at different sites in Tamilnadu are shown in Figure 1 and Figure 2. Typically in these plants, PV modules are installed on iron structure mounted on the roof and it is connected to the array junction box through DC circuit breakers. DC/AC inverters are connected for voltage inversion/ electrical utilization and also for grid connection. PV plant1 uses seven numbers of Fronius IG Plus (150 V-3). $48 \mathrm{PV}$ panels of $250 \mathrm{Wp}$ rating form a single string, so seven strings are needed for $84 \mathrm{kWp}$ system, which is mounted on the roof top in the site. PV plant 2 uses a single Symo 17.5-3-M/FRONIUS. $72 \mathrm{PV}$ panels of $250 \mathrm{Wp}$ rating form a single string. Both PV plants 1 and 2 are installed on a rack structure mounted on the roof top in the site. Energy yield, power, voltage, current and power factor can be sensed by appropriate sensors. These information's are logged into data logger and it can be monitored remotely through web server. PV system and inverter characterization are made in this paper to appropriately select the module and inverter sizing.

Table 1. PV Power Plant Details

\begin{tabular}{ccc}
\hline PV Plant Details & PV Plant 1 & PV Plant 2 \\
\hline Location & Tirunelveli & Ranipet \\
Installed Capacity & $84 \mathrm{~kW}$ & $18 \mathrm{~kW}$ \\
Commissioned on & June 20,2014 & September 04, 2014 \\
Structural Type & Roof mounted with leak proof protection & Flat roof \\
No. of modules & 336 No's of 250 Wp & 72 No's of 250Wp \\
Inverter/make & 150 V- 3/FRONIUS & Symo 17.5-3-M/FRONIUS \\
No's & 7 & 1 \\
Data Monitoring & https://www.solarweb.com/guestlogin & \\
\hline
\end{tabular}

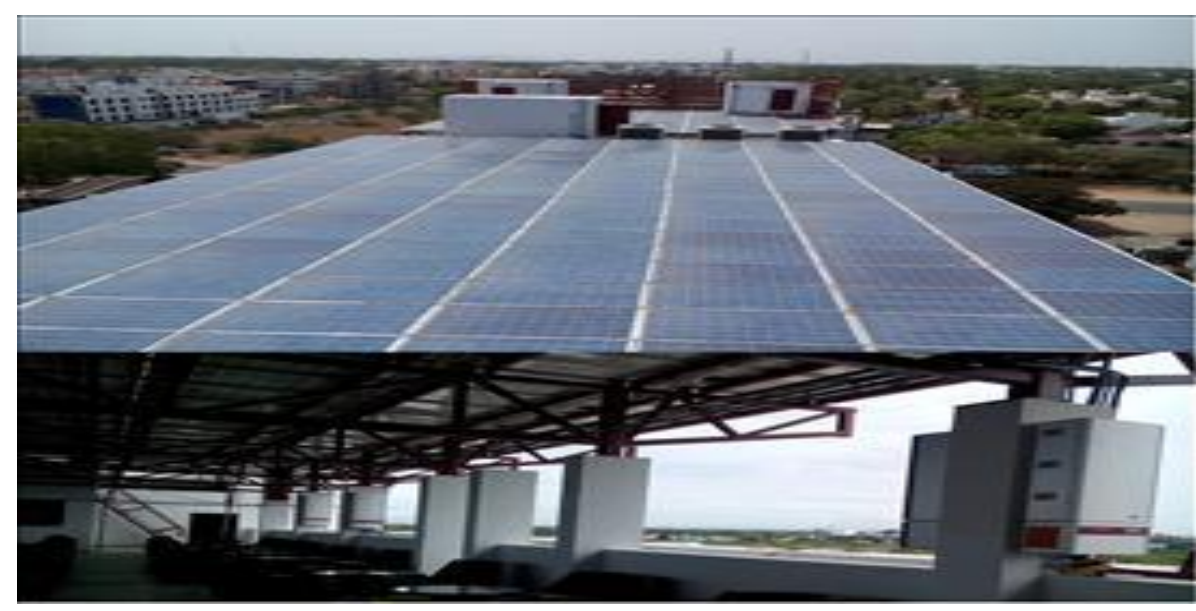

Figure 1. Picture of $84 \mathrm{~kW}$ PV plant at Tirunelveli (PV Plant 1) 


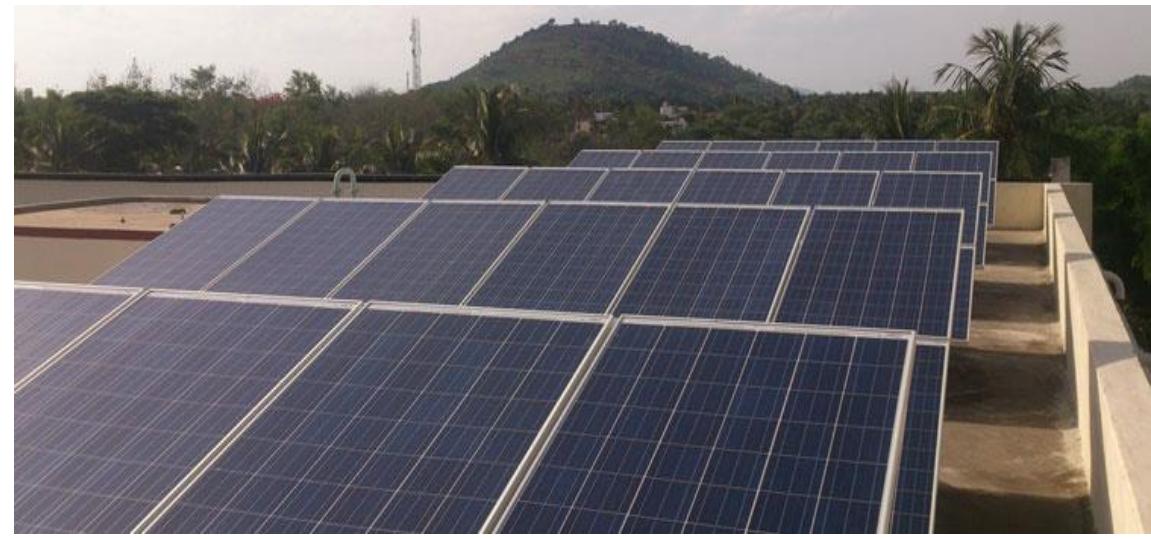

Figure 2. Picture of $18 \mathrm{~kW}$ PV plant at Ranipet (PV Plant 2)

\subsection{Photovoltaic panels}

Photovoltaic panels of rating $240 \mathrm{Wp}$ and $250 \mathrm{Wp}$ of poly crystalline type are used and its electrical specifications at standard test conditions (STC) are given in Table 2.

Table 2. PV Module Specifications

\begin{tabular}{ccc}
\hline Description & \multicolumn{2}{c}{ Value } \\
\hline Type & \multicolumn{2}{c}{ Poly-crystalline } \\
Maximum power, $\mathrm{P}_{\mathrm{m}}(\mathrm{W})$ & $240 \mathrm{Wp}$ & $250 \mathrm{Wp}$ \\
Open circuit voltage, $\mathrm{V}_{\mathrm{oc}}(\mathrm{V})$ & $37.0 \mathrm{~V}$ & $37.2 \mathrm{~V}$ \\
Voltage at max power, $\mathrm{V}_{\mathrm{mp}}(\mathrm{V})$ & $30.60 \mathrm{~V}$ & $30.80 \mathrm{~V}$ \\
Short circuit current, $\mathrm{I}_{\mathrm{sc}}(\mathrm{A})$ & $8.65 \mathrm{~A}$ & $8.96 \mathrm{~A}$ \\
Current at max. power, $\mathrm{I}_{\mathrm{mp}}(\mathrm{A})$ & $7.85 \mathrm{~A}$ & $8.12 \mathrm{~A}$ \\
Module efficiency & $14.78 \%$ & $15.4 \%$ \\
Number of cells & \multicolumn{2}{c}{60} \\
Maximum system voltage & $1000 \mathrm{VDC}$ \\
Module area & $47 \pm 2{ }^{\circ} \mathrm{C}$ \\
Normal Operating Cell Temperature, NOCT & $1.643 \mathrm{~m}^{2}$ \\
Temperature coefficient of current $\left(\mathrm{I}_{\mathrm{sc}}\right) \alpha\left(\% /{ }^{\circ} \mathrm{C}\right)$ & 0.0681 \\
Temperature coefficient of voltage $\left(\mathrm{V}_{\mathrm{oc}}\right) \beta\left(\% /{ }^{\circ} \mathrm{C}\right)$ & -0.2941 \\
Temperature coefficient of power $\left(\mathrm{P}_{\mathrm{m}}\right) \gamma\left(\% /{ }^{\circ} \mathrm{C}\right)$ & \multicolumn{2}{c}{-0.3845} \\
Power specifications at STC: & $1000 \mathrm{~W} / \mathrm{m}^{2} @ 25^{\circ} \mathrm{C}, \mathrm{AM} 1.5$ \\
\hline
\end{tabular}

\subsection{Modelling of PV panel}

The I- $V$ characteristics of PV cell can be expressed by (1) as [29-33]

$$
I=I_{L}-I_{0}\left[\exp \left(\frac{q\left(V+I R_{s}\right)}{n \mathrm{k} \mathrm{T}}\right)-1\right]-\left(\frac{V+I R_{s}}{R_{s h}}\right)
$$

where $I_{\mathrm{L}}$ and $I_{0}$ are the photovoltaic (PV) and reverse saturation currents respectively. $n$ is the diode ideality constant, $q$ is the electron charge $\left(1.60217646 \times 10^{-19} \mathrm{C}\right), k$ is the Boltzmann constant $\left(1.3806503 \times 10^{-23} \mathrm{~J} / \mathrm{K}\right)$, $T_{c}$ (in Kelvin) is the cell temperature. $\mathrm{R}_{\mathrm{s}}$ and $\mathrm{R}_{\mathrm{sh}}$ are series and shunt loss resistances of the PV cell respectively. $R_{s}$ and $R_{s h}$ at standard test conditions (STC) can be expressed as follows:

$$
\begin{aligned}
& R_{s}=\frac{1}{I_{\mathrm{mp}}}\left(V_{\mathrm{cc}}-V_{\mathrm{mp}}-\mathrm{n} \frac{\mathrm{kT}_{\mathrm{c}}}{q} \cdot \ln (\alpha \cdot \beta)\right) \\
& R_{s h}=\frac{V_{\mathrm{mp}} \cdot\left(V_{\mathrm{mp}}-I_{\mathrm{mp}} \cdot R_{s}\right)-\mathrm{n} \mathrm{kT} / q \cdot V_{\mathrm{mp}}}{\left(V_{\mathrm{mp}}-I_{\mathrm{mp}} \cdot R_{s}\right)\left(I_{\mathrm{sc}}-I_{\mathrm{mp}}\right)-\mathrm{n} \mathrm{kT} \mathrm{kT}_{\mathrm{c}} / q \cdot I_{\mathrm{mp}}}
\end{aligned}
$$




$$
\begin{aligned}
& \mathrm{n}=\frac{V_{o c}-V_{\mathrm{mp}}-I_{\mathrm{mp}} . R_{s}}{\mathrm{kT}_{\mathrm{c}} / q \cdot \ln \left(I_{s c} .\left(R_{s}+R_{s h}\right)-V_{o c} /\left(I_{\mathrm{sc}}-I_{\mathrm{mp}}\right) \cdot\left(R_{s}+R_{s h}\right)-V_{\mathrm{mp}}\right)} \\
& \alpha=\frac{V_{\mathrm{mp}}+\mathrm{n} \mathrm{kT}_{\mathrm{c}} / q-I_{\mathrm{mp}} \cdot R_{s}}{\mathrm{n} \mathrm{kT}_{\mathrm{c}} / q} \\
& \beta=\frac{I_{s c} \cdot\left(R_{s}+R_{s h}\right)-V_{o c}}{I_{s c} \cdot\left(R_{s}+R_{s h}\right)-2 \cdot V_{\mathrm{mp}}}
\end{aligned}
$$

The I-V and P- V characteristics of PV panels of rating $240 \mathrm{Wp}$ and $250 \mathrm{Wp}$ are evaluated as shown in Figure 3 and Figure 4 respectively.
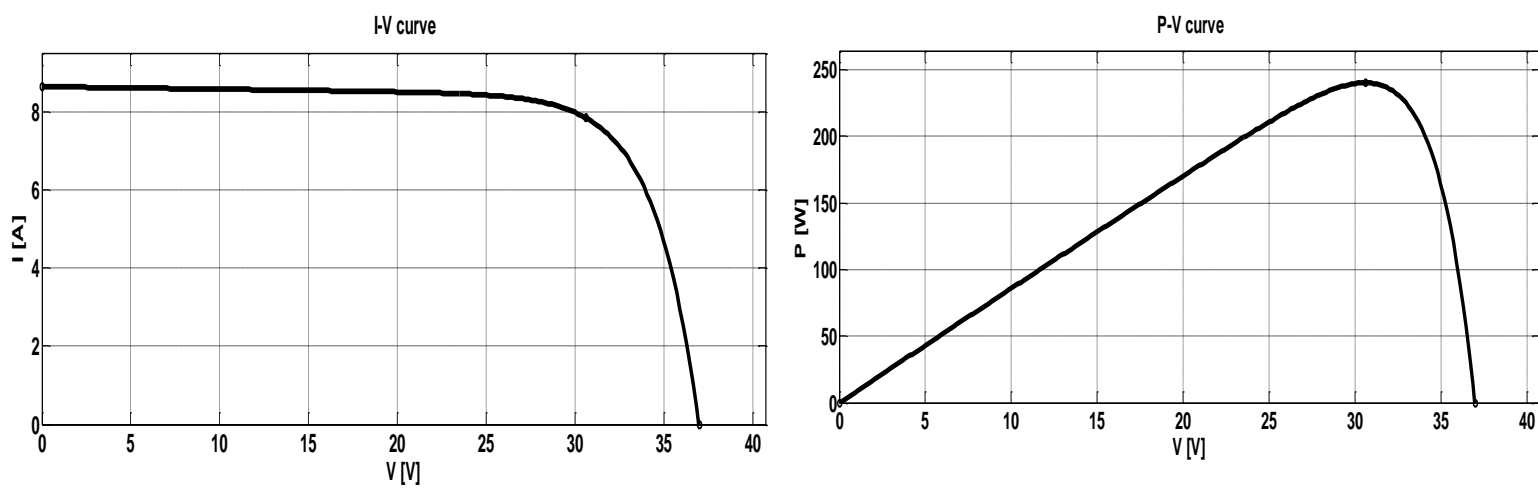

Figure 3. I-V and P-V characteristics of $240 \mathrm{Wp}$ module
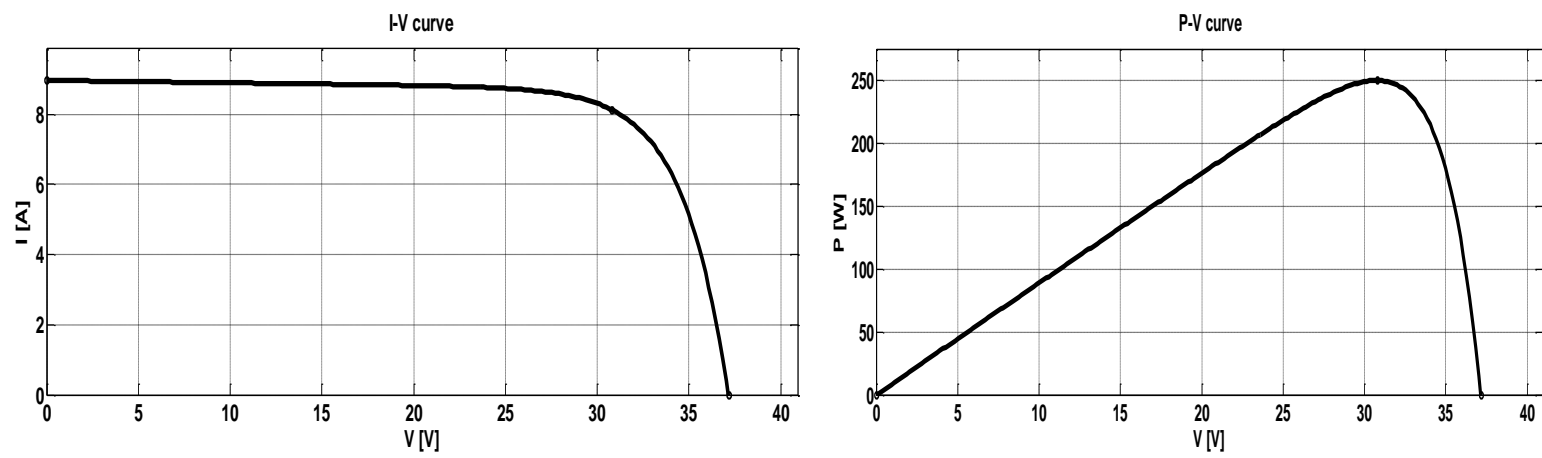

Figure 4. I-V and P-V characteristics of $250 \mathrm{Wp}$ module

Simulations are carried out in Matlab/Simulink environment at STC. The values of $R_{s}$ and $R_{s h}$ are obtained by simulation, which are not mentioned by the manufacturers in data sheet as shown in Table 3 . From these values, based on type of PV panel connection and system rating, entire system impedance can be computed, which will be useful to determine for maximum power transfer and insulation protection purposes.

Table 3. PV Module Obtained Parameters

\begin{tabular}{cccc}
\hline Module & $\begin{array}{c}\mathrm{R}_{\mathrm{s}} \\
\text { (in } \Omega \text { ) }\end{array}$ & $\begin{array}{c}\mathrm{R}_{\text {sh_min }} \\
\text { (in } \Omega \text { ) }\end{array}$ & $\begin{array}{c}\mathrm{R}_{\text {sh }} \\
\text { (in } \Omega \text { ) }\end{array}$ \\
\hline $240 \mathrm{Wp}$ & 0.815287 & 37.434713 & 157.961467 \\
$250 \mathrm{Wp}$ & 0.788177 & 35.878489 & 145.341244 \\
\hline
\end{tabular}




\subsection{Modelling of PV panel}

DC to AC power conversion is achieved with the help of inverters such as Fronius IG Plus (150 V3), Symo 17.5-3-M/FRONIUS. These inverters used are for transformer less configuration. Symo type inverter operates under dual MPPT mode of operation. DC insulation and overload protection are provided in these inverters for additional protection. Online data logging and monitoring facility are incorporated in the system to acquire the performance of the system throughout the year. Web access is provided with the help of WLAN/Ethernet, through Fronius Solar.web, which provide real time data of PV and grid parameters.

\section{PV SYSTEM PERFORMANCE}

The performance of grid connected PV system depends on weather conditions (i.e. incident insolation and ambient temperature), the operation of each individual component (PV panels and inverter) and the connection of the system to the grid. Performance of the photovoltaic systems is observed through reference, array and final yields, performance ratio and capacity utilization factor obtained throughout the year. The monthly energy $\left(\mathrm{E}_{\mathrm{AC}, \mathrm{m}}\right)$ generated by the solar PV power plant is given by (7). The instantaneous energy output is obtained by measuring the energy generated by the PV system after the DC/AC inverter [27].

$$
E_{A C, m}=\sum_{d=1}^{N} E_{A C, d}
$$

where $\mathrm{N}$ is the number of days in the month.

The monthly average array yield $\left(\mathrm{Y}_{\mathrm{A}, \mathrm{m}}\right)$ is defined as the energy output from a $\mathrm{PV}$ array over a month divided by its rated power, given by (8).

$$
Y_{A, m}=\frac{1}{N} \sum_{d=1}^{N} Y_{A, d}
$$

The monthly average final yield $\left(\mathrm{Y}_{\mathrm{F}, \mathrm{m}}\right)$ is defined as net $\mathrm{AC}$ energy output of the system divided by the rated power of the installed PV array at standard test conditions is given by (9) as:

$$
Y_{F, m}=\frac{1}{N} \sum_{d=1}^{N} Y_{F, d}
$$

The reference yield $\left(Y_{R}\right)$ is the total in-plane solar insolation $H_{t}\left(\mathrm{kWh} / \mathrm{m}^{2}\right)$ divided by the array reference irradiance $\left(1 \mathrm{~kW} / \mathrm{m}^{2}\right)$. It is the number of peak sun-hours and is given by (10). In Tamilnadu, the reference yield is almost ranges from 5.6 to 6 hours/day.

$$
Y_{R}=\frac{H_{t}\left(\mathrm{kWh} / \mathrm{m}^{2}\right)}{1\left(\mathrm{kWh} / \mathrm{m}^{2}\right)}
$$

Performance ratio indicates the overall effect of losses on a solar PV array's normal power output depending on array temperature and incomplete utilization of incident radiation. Performance ratio (PR) is expressed by (11).

$$
P R=\frac{Y_{F}}{Y_{R}}
$$

\subsection{Geographical information systems (GIS)}

GIS portal on Tamilnadu renewable energy resources have assessed solar PV potential of various districts and taluks in Tamilnadu. It provides the maps and overlays for solar PV systems with annual global horizontal irradiation (GHI) in terms of $\mathrm{kWh} / \mathrm{m}^{2}$. The solar PV potential for Tirunelveli and Ranipet are found to be 631.29 MW and 1248.14 MW respectively. Photovoltaic Geographical Information System (PVGIS), an online free solar photovoltaic energy calculator is used to estimate energy yield for stand alone or grid connected PV systems, which provides interactive maps for understanding the geographic dependency 
of the performance of the PV technologies [34]. PVGIS statistics of these plants such as estimated losses due to temperature and low irradiance, angular reflectance effects and other losses (cables, inverter etc.) under study are found to be 14.0-15.2\%, $2.7 \%$ and $14.0 \%$ respectively. The combined PV system losses are about $28.1 \%$ individually for each system.

Table 4. PVGIS statistics for the PV plants under evaluation

\begin{tabular}{ccc}
\hline Plant & $\begin{array}{c}\text { Nominal power of the PV system } \\
(\mathrm{kW})\end{array}$ & $\begin{array}{c}\text { Expected power generation in eight months } \\
(\mathrm{kWh})\end{array}$ \\
\hline PV Plant 1 & 84.0 & 88460 \\
PV Plant 2 & 18.0 & 17000 \\
\hline
\end{tabular}

\section{PERFORMANCE EVALUATION AND DISCUSSIONS}

The results and performance observation of the two PV solar power plants installed in different parts of Tamilnadu are carried out for the period from September 1, 2014 to April 30, 2015 are discussed in this section. The observations of various parameters measured such as monthly average generation and carbondioxide $\left(\mathrm{CO}_{2}\right)$ savings during operation of PV plants are mentioned. The operation of these PV plants starts normally at 6:15 a.m in the morning and goes up to 6:30 p.m in the evening. Significant amount of power generation normally occurs between 10:00 a.m to 3:00 p.m. Data monitoring is carried out on minute basis and aggregated for every 15 minute intervals and stored in the logger system. Complete operation data from the logger for the observed period are also mentioned.

PV plant 1 generates about 43.97 MWh for the period of eight months, (i.e.) $49.70 \%$ of prediction made by PVGIS. The highest power generation was available in its commissioned month (i.e.) September, 2014 of about $7732.32 \mathrm{kWh}$ with $\mathrm{CO}_{2}$ savings of $4100 \mathrm{~kg} \mathrm{CO}_{2}$ and the lower value recorded in the month of December 2014 of generation $2683.67 \mathrm{kWh}$ with $\mathrm{CO}_{2}$ savings of $1420 \mathrm{~kg} \mathrm{CO}$. It experiences zero power generation for five days in the month of December 2014 due to bad weather and failure in inverters. This can be observed as zero reading from the data logger. The highest and lowest generations recorded on 346.15 $\mathrm{kWh}$ (08 September 2014) and $101.91 \mathrm{kWh}$ respectively.

During the same period of eight months, PV plant 2 generates about $15553.29 \mathrm{kWh}$, almost $91.23 \%$ as predicted by PVGIS. The highest and lowest generation recorded on any day is $100.06 \mathrm{kWh}$ and 44.02 $\mathrm{kWh}$ respectively. The highest power generation recorded in the month of April, 2015 of value $2799.38 \mathrm{kWh}$ with $\mathrm{CO}_{2}$ savings of $1480.0 \mathrm{~kg} \mathrm{CO}$ and the lowest value recorded in the month of December 2014 of generation $1356.39 \mathrm{kWh}$ with $\mathrm{CO}_{2}$ savings of $714.89 \mathrm{~kg} \mathrm{CO}_{2}$.

The average monthly energy generated and monthly average array yield by the PV plants are calculated using the (7) and (8). The daily energy generation of PV plants 1 and 2 over the monitored period are shown in Figure 5 and Figure 6 respectively. The monthly energy generation and $\mathrm{CO}_{2}$ savings of these PV plants are shown in Figure 7 and Figure 8 respectively.

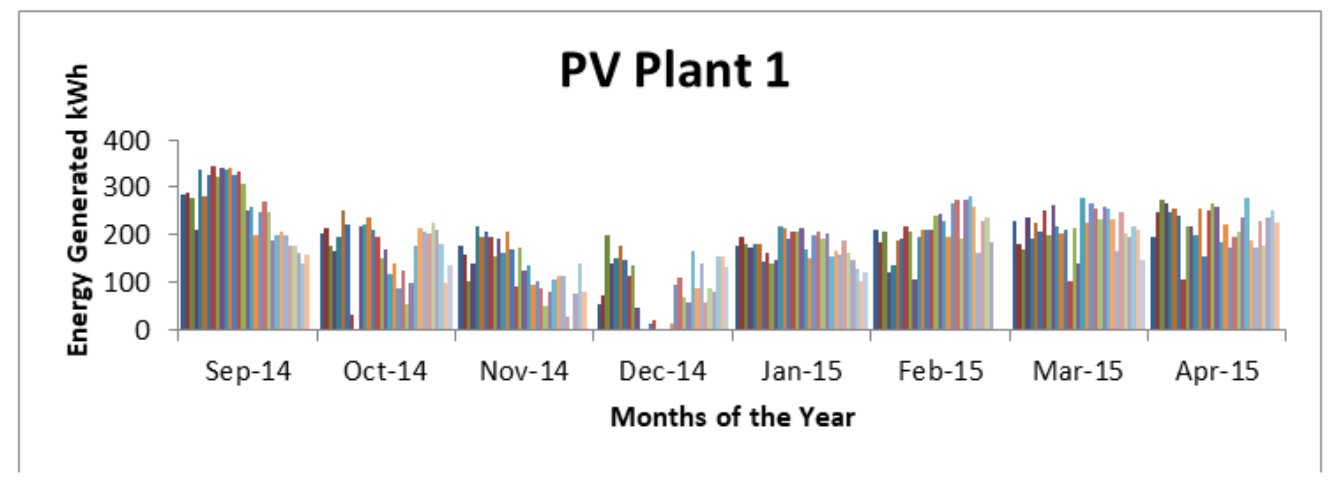

Figure 5. Daily energy generation of PV plant 1 over the monitored period 


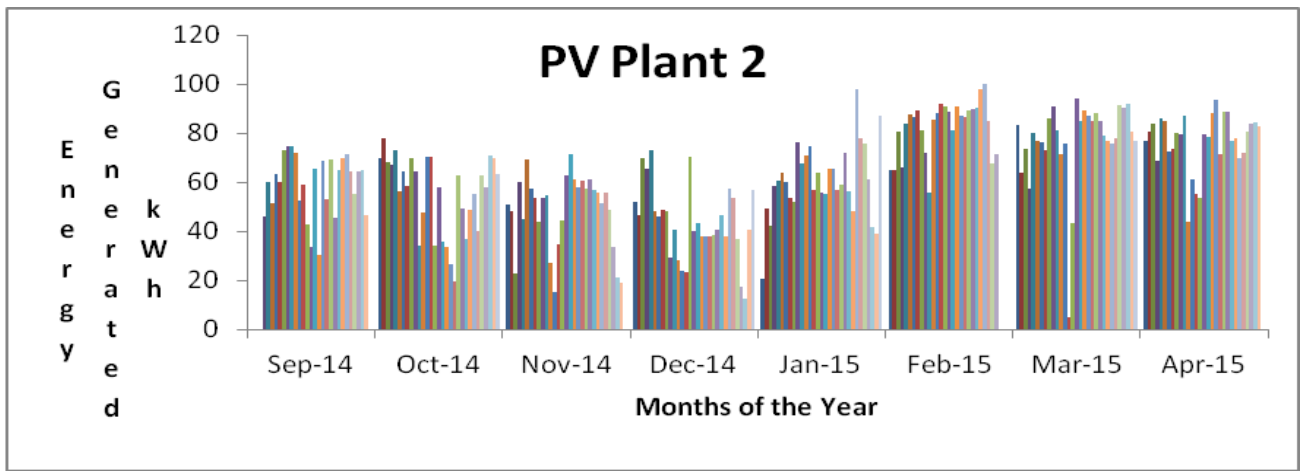

Figure 6. Daily energy generation of PV plant 2 over the monitored period

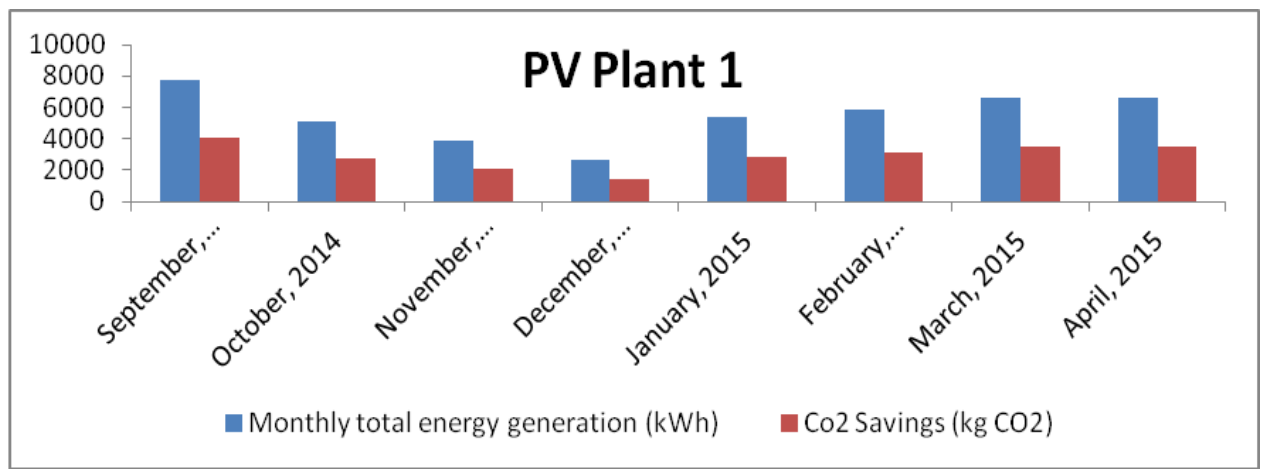

Figure 7. Monthly total energy generation and $\mathrm{CO}_{2}$ savings of PV plant 1

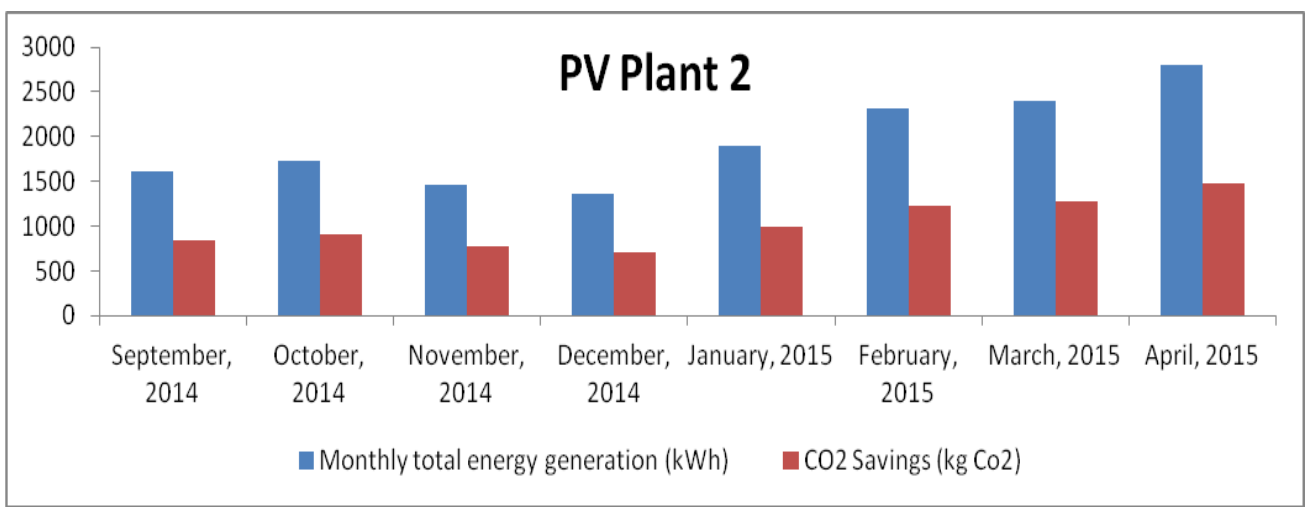

Figure 8. Monthly total energy generation and $\mathrm{CO}_{2}$ savings of PV plant 2

The monthly average array yield of PV plant 1varied from a lower value of 0.99 hours/day in the month of December to a maximum value of 2.76 hours/day in the month of September. Array yield of PV plant 2 varied from a lower value of 2.34 hours/day in the month of December to a maximum value of 4.67 hours/day in the month of April. It can be inferred that the fall in energy generation is mainly influenced by climatic conditions (rainy and cloudy days). The monthly average array yields of these PV plants are given in Figure 9. 


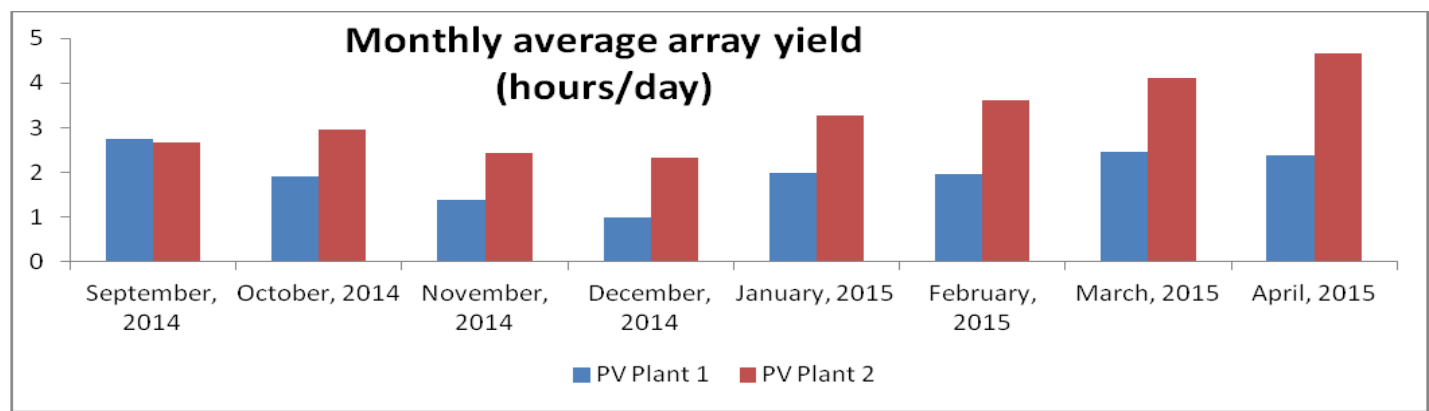

Figure 9. Monthly average array yields of PV plants

Performance ratio (PR) is used to indicate the various losses on the rated output of the system. The performance ratios of these PV plants are calculated for the entire period of evaluation (i.e.) from September 2014 to April 2015 as shown in the Figure 9. PR of PV plant 1 is less because there was substantial loss of energy generation in the month of December. The PV plant 2 has higher PR value of 86.16\%. The performance of these PV plants are observed through voltages (AC and DC voltages), current and power waveforms which are measured every $15 \mathrm{~min}$.

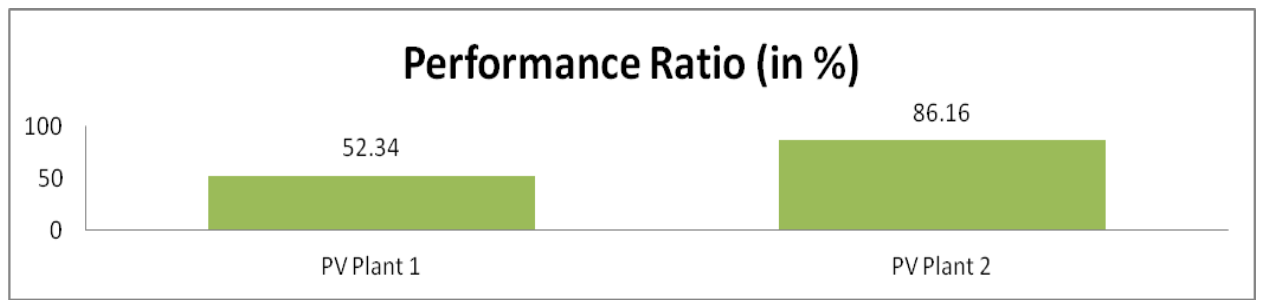

Figure 10. Average performance ratio of PV plants over the entire monitored period

The output AC power was recorded and averaged after every $15 \mathrm{~min}$ interval. Screenshot of the online monitoring of PV plant 1 is shown in Figure 11 to Figure 13. The maximum performance of PV plant1 is obtained on 08 September 2014 having generation of about $346.15 \mathrm{kWh}$. The power obtained from the entire PV system fed through the connected 7 inverters is shown in Figure 11.

\section{$346.15_{\mathrm{kWh}}$ 08.09.2014}

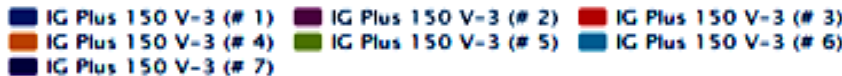

100

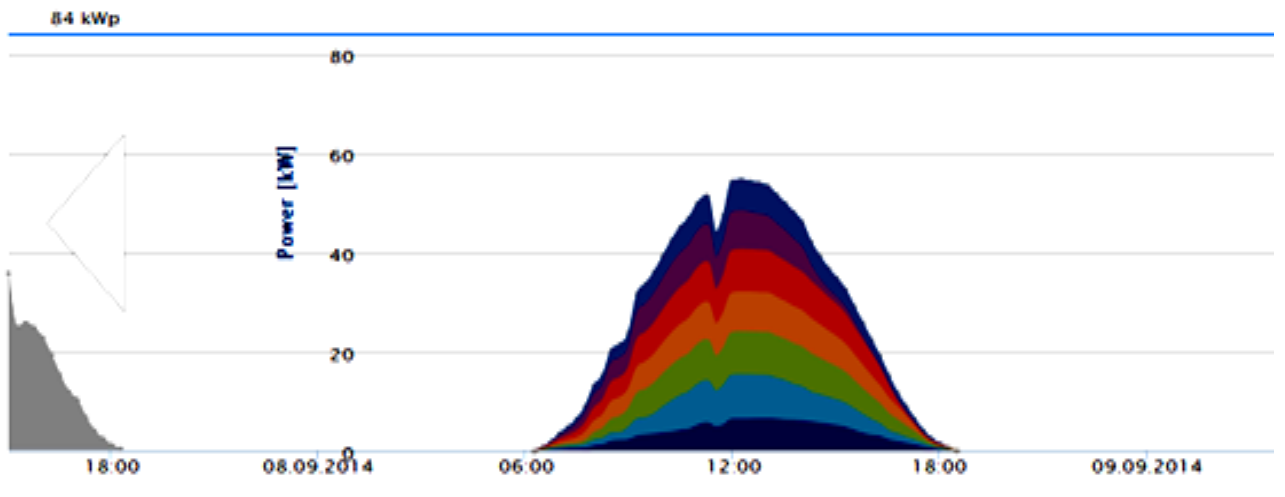

Figure 11. Power waveforms obtained from all the inverters of PV plant1 
The DC parameters such as dc voltage and current waveforms are also recorded. The voltage starts to build up at 6:00 a.m at about 280-290 V DC and reaches maximum value at 12:15 p.m ranging from 295$330 \mathrm{~V}$ DC and current of value 21-27 A DC to all the 7 inverters as shown in Figure 12.Inversion action takes place with the help of these 7 inverters and the AC parameters such as line and phase voltages and current waveforms are also observed. The line voltage ranges through a mean value of $400-420 \mathrm{~V}$ throughout the day, so the phase voltages have the value of about 227-241 V. The current reaches the maximum value of 12.24 A and the power generation is $54.65 \mathrm{~kW}$ at 12:15 p.m as shown in Figure 13. The obtained voltages match with the grid requirement of $230 \mathrm{~V} /$ phase, so it can be grid connected.

\subsection{5kWh 08.09 .2014

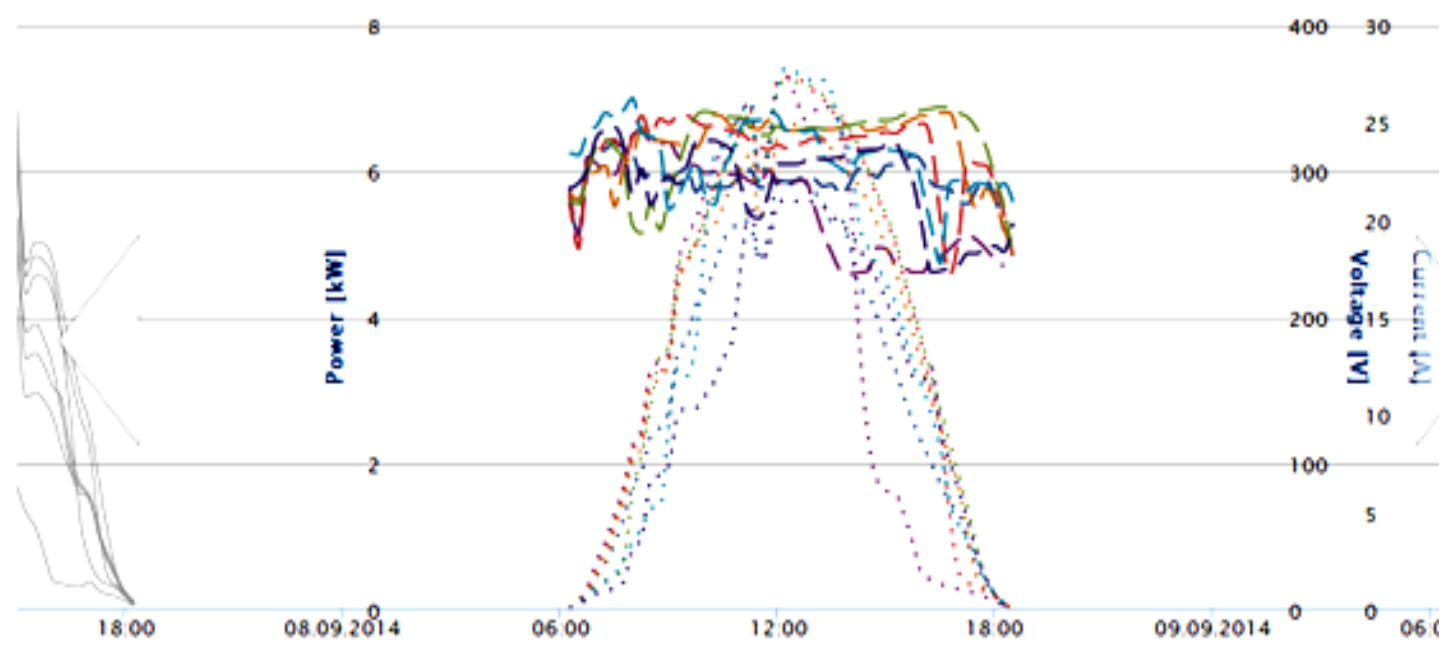

Figure 12. DC voltage and current waveforms of PV plant1 (Broken thick lines are dc voltage waveforms and dotted lines are dc current waveforms of the inverters)
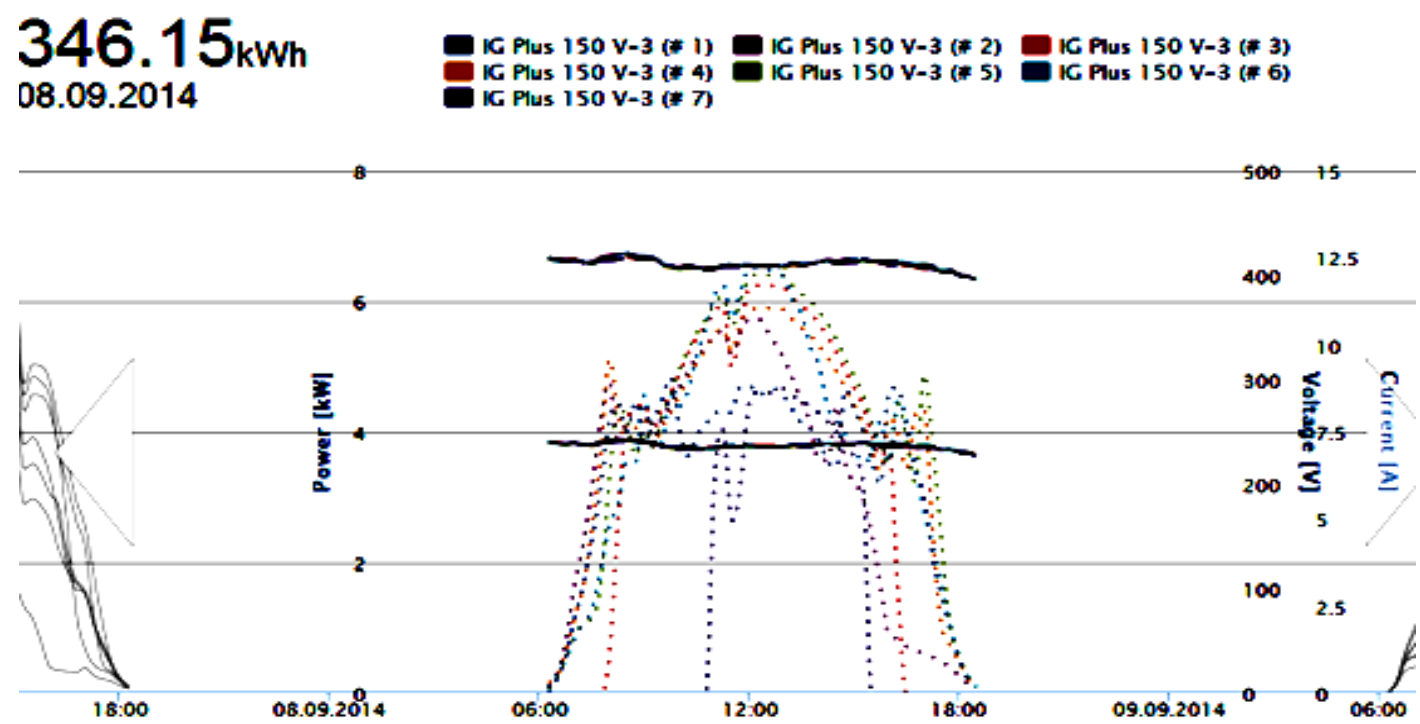

Figure 13. AC line / phase voltage and current waveforms of PV plant1 (Thick lines located at the top and middle are line and phase voltage wave forms respectively and dotted lines are current waveforms of the inverters) 


\section{CONCLUSION}

Performance analysis have been carried out for roof top solar photo voltaic plants in different geographic locations of Tamilnadu for the period September 2014 to April 2015 having similar operating conditions such as solar insolation, temperature and other climatic conditions. The important conclusions arrived based on the equipment evaluation of these plants are listed as 1) Modelling of PV panels and their series and shunt loss resistances are determined, which give valuable information about system behavior to PV system designers.2) The average monthly energy generated by these PV1 and PV2 plants are 5499.84 $\mathrm{kWh}$, and $1944.16 \mathrm{kWh}$ respectively.3) The monthly average array yields of these PV plants are around 2.85 hours/day in these locations of Tamilnadu. 4) The $\mathrm{CO}_{2}$ emissions of these plants are also accounted which shows that the power generated is clean and environmental friendly. 5) The performance ratios (PR) of these plants are 0.52 and 0.86 respectively. PR ratios are found to be high in the northern parts of Tamilnadu (PV plant2), whereas the land cost is cheap in southern part (PV plant 1). So many solar power parks are proposed to be commissioned in these coming years. 6) Performances of the employed inverters are observed. 7) The initiatives made by government through policies are also highlighted. Based on the findings from this study, the development of roof top grid connected solar PV system in various parts of Tamilnadu could be made viable and motivate others for widespread adaptation.

\section{ACKNOWLEDGEMENTS}

The author would like to acknowledge KCP Solar Industries, Salem, Tamilnadu for their support and fruitful discussions. The authors are extremely grateful to the anonymous reviewers for their comments and suggestions, which really helped to improve the quality of the paper substantially.

This work was supported by Wind Energy Division, Ministry of New \& Renewable Energy, Government of India under financial grant (IFD Dy. No. 1429 dated 04/11/2016, Demand No. 61/69, Budget Head: 2810:00.104.04.05.31/35).

\section{REFERENCES}

[1] Akash Kumar Shukla, K. Sudhakara, Prashant Baredar, Rizalman Mamat, "Solar PV and BIPV system: Barrier, challenges and policy recommendation in India," Renewable and Sustainable Energy Reviews, vol. 82, pp.3314-3322, 2018.

[2] Sourabh Jain, Nikunj Kumar Jain, W. Jamie Vaughn, "Challenges in meeting all of India's electricity from solar: An energetic approach," Renewable and Sustainable Energy Reviews, vol. 82, pp. 1006-1013, 2018.

[3] S. Manju, Netramani Sagar, "Progressing towards the development of sustainable energy: A critical review on the current status, applications, developmental barriers and prospects of solar photovoltaic systems in India," Renewable and Sustainable Energy Reviews,vol. 70, pp. 298-313, 2017.

[4] https://mnre.gov.in/[Accessed on 10 October 2018]

[5] Pushpendra Kumar Singh Rathore, Shailendra Rathore, Rudra Pratap Singh, Sugandha Agnihotri, "Solar power utility sector in India: Challenges and opportunities," Renewable and Sustainable Energy Reviews, vol. 81, pp. 2703-2713, 2018

[6] https://www.tangedco.gov.in/ Tamilnadu Generation and Distribution Corporation Limited (TANGEDCO), Government of Tamilnadu, [Accessed on 24 May 2018].

[7] http://www.investingintamilnadu.com/tamilnadu/doc/why_tamilnadu/presentation-on-tamil-nadu-31-july-2018.pdf [Accessed on 27 September 2018].

[8] http://teda.in/teda-solicits-comments-on-the-draft-solar-policy-2018/[Accessed on 27 September 2018].

[9] M. M. Fouad, Lamia A. Shihata, ElSayed I. Morgan, "An integrated review of factors influencing the performance of photovoltaic panels," Renewable and Sustainable Energy Reviews, vol. 80, pp. 1499 -1511, 2017.

[10] Manish Kumar and Arun Kumar, "Performance assessment and degradation analysis of solar photovoltaic technologies: A review, "Renewable and Sustainable Energy Reviews, vol. 78, pp. 554 -587, 2017.

[11] A. A. Babatunde, S. Abbasoglu, M. Senol, "Analysis of the impact of dust, tilt angle and orientation on performance of PV Plants," Renewable and Sustainable Energy Reviews, vol. 90, pp. 1017 -1026, 2018.

[12] Kumar KA, Sundareswaran K, Venkateswaran PR., "Performance study on a grid connected $20 \mathrm{kWp}$ solar photovoltaic installation in an industry in Tiruchirappalli (India)," Energy for Sustainable Development, vol. 23, pp.294-304., 2014.

[13] Sivasankari S, Sarat Chandra Babu J, "Performance evaluation and validation of $5 \mathrm{MWp}$ grid connected solar photovoltaic plant in South India," Energy Conversion Management, vol. 100, pp. 429-439, 2015.

[14] Tripathi B, Yadav P, Rathod S, Kumar M, "Performance analysis and comparison of two silicon material based photovoltaic technologies under actual climatic conditions in Western India," Energy Conversion Management, vol. 80, pp.97-102, 2014.

[15] Moharil RM, Kulkarni PS, "A case study of solar photovoltaic power system at Sagardeep Island, India," Renewable and Sustainable Energy Reviews, vol.13, pp. 673-681, 2013.

[16] Sharma V, Chandel SS, "Performance analysis of a $190 \mathrm{kWp}$ grid interactive solar photovoltaic power plant in India," Energy, vol.55,pp. 476-485., 2013. 
[17] Padmavathi K, Arul Daniel S, "Performance analysis of a 3 MWp grid connected solar photovoltaic power plant in India," Energy for Sustainable Development, vol.17, pp. 615-625., 2013.

[18] Aaditya G, Pillai R, Mani M, "An insight into real-time performance assessment of a building integrated photovoltaic (BIPV) installation in Bangalore (India), "Energy for Sustainable Development, vol.17, pp.431-437, 2013.

[19] J. Raja, Nishant Jain, C. Christober Asir Rajan, "Grid connected mega-watt range solar power plant in India: experimental measurement \& performance analysis, International Journal of Applied Power Engineering (IJAPE), Vol.8, No.1, April 2019, pp. 22 33.

[20] Ayompe LM, Duffy A, McCormack SJ, Conlon M, "Measured performance of a $1.72 \mathrm{~kW}$ rooftop grid connected photovoltaic system in Ireland," Energy Conversion Management, vol.52,pp. 816-825, 2011.

[21] Congedo PM, Malvoni M, Mele M, De Giorgi MG, "Performance measurements of mono crystalline silicon PV modules in South-eastern Italy," Energy Conversion Management, vol.68, pp. 1-10, 2013.

[22] Milosavljević DD, Pavlovića TM, Piršl DS, "Performance analysis of a grid-connected solar PV plant in Niš, republic of Serbia," Renewable and Sustainable Energy Reviews, vol.44, pp. 423-435, 2015.

[23] Mpholo M, Nchaba T, Monese M, "Yield and performance analysis of the first grid-connected solar farm at Moshoeshoe International Airport, Lesotho," Renewable Energy, vol.81, pp.845-852, 2015.

[24] Wittkopf S, Valliappan S, Liu L, Ang KS, Cheng SCJ, "Analytical performance monitoring of a $142.5 \mathrm{kWp}$ grid-connected rooftop BIPV system in Singapore, "Renewable Energy, vol.47, pp.9-20, 2012.

[25] Ghiani E, Pilo F, Cossu S, "Evaluation of photovoltaic installations performances in Sardinia, "Energy Conversion Management, vol.76, pp. 1134-1142, 2013.

[26] Micheli D, Alessandrini S, Radu R, Casula I, "Analysis of the outdoor performance and efficiency of two grid connected photovoltaic systems in northern Italy," Energy Convers Manage 2014; 80:436-445.

[27] Al-Otaibi A, Al-Qattan A, Fairouz F, Al-Mulla A, "Performance evaluation of photovoltaic systems on Kuwaiti schools rooftop," Energy Conversion Management, vol.95, pp. 110-119, 2015.

[28] Okello D, Van Dyk EE, Vorster FJ, "Analysis of measured and simulated performance data of a $3.2 \mathrm{kWp}$ gridconnected PV system in Port Elizabeth, South Africa," Energy Conversion Management, vol.100, pp. 10-15, 2015.

[29] Kumar, M and Kumar, A, "An efficient parameters extraction technique of photovoltaic models for performance assessment," Solar Energy, vol.158, pp.192-206, 2017.

[30] Salah Eddine Mankour, Ahmed Wahid Belarbi, Mohammed Tarik Benmessaoud, "Modeling and Simulation of a Photovoltaic Field for $13 \mathrm{KW}, "$ International Journal of Electrical and Computer Engineering, vol. 7, pp. 3271-3281, 2017.

[31] Farhoodnea M, Mohamed A, Khatib T, Elmenreich W, "Performance evaluation and characterization of a 3-kWp grid-connected photovoltaic system based on tropical field experimental results: new results and comparative study," Renewable and Sustainable Energy Reviews, vol.42, pp. 1047-1054, 2015.

[32] Sobhan Dorahaki, "Evaluating the radiation and temperature effect on photovoltaic systems," Bulletin of Electrical Engineering and Informatics, vol. 4, pp.1-6., 2015.

[33] Ali M. Humada, Ashty M. Aaref, Hussein M. Hamada, Mohd Herwan Sulaiman, Nowshad Amin, Saad Mekhilef, "Modeling and characterization of a grid-connected photovoltaic system under tropical climate conditions," Renewable and Sustainable Energy Reviews, vol.82, pp. 2094-2105, 2018.

[34] http://re.jrc.ec.europa.eu/pvg_tools/en/tools.html [Accessed on 24 May 2018]. 